Theories \& Applications, the International Edition

Printed Version: (ISSN 2090-5262)

Online Version: (ISSN 2090-5270)

November 2012, Volume 2, No. 3 Pages (11 - 16)

\title{
The Effect of Harmonic Ability on the Performance of 100m Hurdles for Students in the Faculty of Physical Education
}

\author{
Nebal Ahmed Hassan Badr*
}

\begin{abstract}
:
The research aims to design a program for the development of the harmonic ability of $100 \mathrm{~m}$ hurdles race and to identify its effect on the level of performance (technical, digital).the main research sample included a 40 student actually that has been divided into two groups: the first is experimental and the other is controlled. Each of them consists of 20 student. The researcher used the harmonic abilities tests for $100 \mathrm{~m}$. hurdles to collect data. the most important results were that there are statistic differences between the two post measurements averages of the two research groups in the harmonic abilities and the performance level ( technical and digital) for the experimental group.
\end{abstract}

\section{Introduction and Research Problem:}

$\mathrm{T}$ he hurdles are regarded as the core of Balamadmar races which earn the individual agility, flexibility and muscle nervous consensus and suitable rhythm motor for performance as well as it is characterized by fun and excitement. the harmonic ability is regarded as the most important aspects of motor development, through it all the muscles included work in cooperation and consistency and it,s an evidence of the muscle groups activity that work in activity series through time and place and thus movement becomes useful (6: 336), both Abu Ala Abdel-Fattah, Jensen \& Fishe and Jamal Hamadeh, Salah Naga refer that every sporting activity have a special consensual ability that characterizes of the other activities . Motor performance in activities requires a high degree of motor coordination and compatibility (1:33) (8: 149) (4: 234), as each of Allawi, wolf Droge and Essam Abdel Khalek refer that harmonic ability is closely linked to the development of technical motor skills and Specialist Activity determines the quality of These abilities that must be developed as the individual cannot master the technical skills the specialist activity in case of lacking the harmonic abilities of this activity (3: 80) (11:

* Lecturer, Department of Physical Education, Menoufia University, Sadat Branch, Egypt.
185) (2: 188), and Mohamed Sobhi Hassanein confirms that beginners who lose certain amount of harmonic ability that caused a great difficulty in access to the mechanism of performance as well as the lack of balance between the movements and its results of the skills that have a level of difficulty in the performance (6: 114), and Matthews adds that the process of learning motor skills are faster and more effective if the attention was paid to improving the harmonic abilities that form an important variable to facilitate motor skills performance (9: 125), and through the work of researcher and her experience noted the difficulty in learning the consensus motor of the 100-meter hurdles, where hurdles are perceived as a compound skill because of its technical laws as well as the beginning female students' fear and anxiety of crashing with hurdles and the fall of their technical and digital level. Also, there is a lack of paying attention to the development of the harmonic abilities of hurdles, which are important in the improvement of the performance so the researcher thought in this study.

\section{Experience:}

The researcher used the experimental method and the research sample included 50 female students from the second year in the Faculty of 
Physical Education, University of Menoufia .The researcher has excluded a number of 10 female students to make the survey. Thus the actual research sample became 40 female student that have been divided into two groups: the first is experimental and the other is control. Each of them consists of 20 female student and researcher applied on the experimental group the proposed program of harmonic abilities for 6 weeks by 3 lectures per a week and the time of the Lecture is 90 minutes. The researcher has Results: made a homogeneity for the research sample to make sure of the modesty of the research sample's members distribution. Also she has made a balance of the two research groups in variables (age, height and weight) and Tests harmonic abilities variable (speed - Rhythm link - Balance - Response - voltage regulation) and variables of technical and digital performance level as well as making the scientific transactions for the used tests.

Table (1)

Significant differences between the average of the pre and post experimental group tests of harmonic consistent

$n=20$

\begin{tabular}{|c|c|c|c|c|c|c|c|c|}
\hline \multirow{2}{*}{\multicolumn{3}{|c|}{ Harmonic abilities tests }} & \multicolumn{2}{|c|}{ Pre- measurement } & \multicolumn{2}{|c|}{ Post measurement } & \multirow{2}{*}{$\begin{array}{c}\text { The } \\
\text { difference } \\
\text { between the } \\
\text { two averages }\end{array}$} & \multirow[b]{2}{*}{ "t" value } \\
\hline & & & Mean & $\begin{array}{l}\text { Standard } \\
\text { deviation }\end{array}$ & Mean & $\begin{array}{l}\text { Standard } \\
\text { deviation }\end{array}$ & & \\
\hline \multicolumn{3}{|c|}{ Speed } & 6.11 & 0.33 & 4.49 & 0.49 & 1.62 & $* 13.92$ \\
\hline \multicolumn{3}{|c|}{ Rhythm } & 3.70 & 0.57 & 7.55 & 0.51 & 3.85 & $* 21.19$ \\
\hline \multicolumn{3}{|c|}{ Link } & 13.55 & 0.61 & 11.30 & 0.49 & 2.25 & $* 26.16$ \\
\hline \multicolumn{3}{|c|}{ Balance } & 64.75 & 6.61 & 70.85 & 5.45 & 6.10 & *11.67 \\
\hline \multicolumn{3}{|c|}{ Quick respond } & 8.23 & 0.42 & 7.57 & 0.34 & 0.66 & $* 8.30$ \\
\hline \multirow{6}{*}{$\begin{array}{l}\text { voltage } \\
\text { regulation }\end{array}$} & \multirow{2}{*}{$\begin{array}{l}\text { From the beginning to } \\
\text { the first hurdle }\end{array}$} & time & 4.47 & 0.57 & 3.52 & 0.42 & 0.95 & $* 6.47$ \\
\hline & & form & 1.55 & 0.51 & 1.85 & 0.37 & 0.30 & $* 2.85$ \\
\hline & \multirow{2}{*}{ Among hurdles } & time & 10.47 & 0.47 & 8.67 & 0.61 & 1.80 & $* 20.32$ \\
\hline & & form & 1.40 & 0.50 & 4.70 & 0.66 & 3.30 & $* 31.39$ \\
\hline & \multirow{2}{*}{$\begin{array}{l}\text { From the last hurdle } \\
\text { to the end line }\end{array}$} & time & 3.55 & 0.32 & 2.81 & 0.42 & 0.74 & $* 7.07$ \\
\hline & & form & 1.30 & 0.47 & 1.9 & 0.31 & 0.60 & $* 5.34$ \\
\hline
\end{tabular}

The value of " $v^{\prime \prime}$ indexed at the level $(0.05)=2.09$

It is clear from the table (1) that there are in harmonic abilities tests and in favor of the significant differences between the average of average of post measurement.

the pre and post tests in the experimental group

Table (2)

Significant differences between the average of the pre and post measurements of the experimental group in variables of the performance level and Digital level $n=20$

\begin{tabular}{|c|c|c|c|c|c|c|c|}
\hline & \multirow[b]{2}{*}{ Variables } & \multicolumn{2}{|c|}{ Post measurement } & \multicolumn{2}{|c|}{ Post measurement } & \multirow{2}{*}{$\begin{array}{c}\text { The } \\
\text { difference } \\
\text { between the } \\
\text { two averages }\end{array}$} & \multirow[b]{2}{*}{ "t" value } \\
\hline & & Mean & $\begin{array}{l}\text { Standard } \\
\text { deviation }\end{array}$ & Mean & $\begin{array}{l}\text { Standard } \\
\text { deviation }\end{array}$ & & \\
\hline \multirow{4}{*}{$\begin{array}{l}\text { Technical } \\
\text { performance level }\end{array}$} & $\begin{array}{l}\text { From the beginning to } \\
\text { the first hurdle }\end{array}$ & 1.93 & 0.52 & 3.68 & 0.37 & 1.75 & *18.92 \\
\hline & Passing over the hurdle & 0.98 & 0.34 & 2.60 & 0.35 & 1.62 & $* 32.72$ \\
\hline & Running among hurdles & 1.60 & 0.21 & 3.35 & 0.33 & 1.75 & $* 25.79$ \\
\hline & $\begin{array}{l}\text { From the last hurdle to } \\
\text { the end line }\end{array}$ & 1.75 & 0.38 & 3.30 & 0.34 & 1.55 & *19.30 \\
\hline \multicolumn{2}{|c|}{ Digital level } & 28.42 & 0.91 & 22.30 & 1.14 & 6.12 & $* 36.93$ \\
\hline
\end{tabular}

The value of " $v$ " indexed at the level $(0.05)=2.09$

It is clear from Table (2) that there are significant differences between the average of the pre and post measurements of the experimental group in variables of performance level and digital level for the post measurement average. 
Table (3)

Significant differences between the average of pre and post measurements for the control group in the harmonic tests consistent

$n=20$

\begin{tabular}{|c|c|c|c|c|c|c|c|c|}
\hline \multirow{2}{*}{\multicolumn{3}{|c|}{ Harmonic ability tests }} & \multicolumn{2}{|c|}{ Pre- measurement } & \multicolumn{2}{|c|}{ Post measurement } & \multirow{2}{*}{$\begin{array}{c}\text { The } \\
\text { difference } \\
\text { between the } \\
\text { two averages }\end{array}$} & \multirow[b]{2}{*}{ "t" value } \\
\hline & & & Mean & $\begin{array}{l}\text { Standard } \\
\text { deviation }\end{array}$ & Mean & $\begin{array}{l}\text { Standard } \\
\text { deviation }\end{array}$ & & \\
\hline \multicolumn{3}{|c|}{ Speed } & 6.16 & 0.34 & 4.98 & 0.46 & 1.18 & $* 15.05$ \\
\hline \multicolumn{3}{|c|}{ Rhythm } & 3.70 & 0.66 & 6.60 & 0.75 & 2.90 & $* 12.70$ \\
\hline \multicolumn{3}{|c|}{ Link } & 13.56 & 0.59 & 12.24 & 0.57 & 1.32 & $* 14.22$ \\
\hline \multicolumn{3}{|c|}{ Balance } & 64.65 & 6.37 & 68.25 & 5.34 & 3.60 & $* 5.40$ \\
\hline \multicolumn{3}{|c|}{ Quick respond } & 8.20 & 0.38 & 7.99 & 0.33 & 0.21 & $* 3.16$ \\
\hline \multirow{6}{*}{$\begin{array}{l}\text { Voltage } \\
\text { regulation }\end{array}$} & \multirow{2}{*}{$\begin{array}{l}\text { From the } \\
\text { beginning to the } \\
\text { first hurdle }\end{array}$} & Time & 4.40 & 0.46 & 3.98 & 0.39 & 0.42 & $* 3.12$ \\
\hline & & Form & 1.53 & 0.51 & 1.80 & 0.41 & 0.27 & $* 2.52$ \\
\hline & \multirow{2}{*}{ Among hurdles } & Time & 10.46 & 0.69 & 9.75 & 0.60 & 0.71 & $* 7.51$ \\
\hline & & Form & 1.45 & 0.51 & 2.90 & 1.02 & 1.45 & $* 7.09$ \\
\hline & \multirow{2}{*}{$\begin{array}{l}\text { From the last } \\
\text { hurdle to the end } \\
\text { line }\end{array}$} & Time & 3.57 & 0.30 & 3.08 & 0.34 & 0.49 & $* 8.25$ \\
\hline & & Form & 1.35 & 0.49 & 1.75 & 0.44 & 0.40 & $* 3.94$ \\
\hline
\end{tabular}

The value of " $v^{\prime \prime}$ indexed at the level $(0.05)=2.09$

It is clear from Table (3) that there are in tests of harmonic ability and for mean post significant differences between the average of measurement.

pre and post measurements for the control group

Table (4)

Significant differences between the average of pre and post measurements for the control group variables in the level of performance and Digital level

$n=20$

\begin{tabular}{|c|c|c|c|c|c|c|c|}
\hline \multirow{2}{*}{\multicolumn{2}{|c|}{ Variables }} & \multicolumn{2}{|c|}{ Pre- measurement } & \multicolumn{2}{|c|}{ Post measurement } & \multirow{2}{*}{$\begin{array}{c}\text { The } \\
\text { difference } \\
\text { between the } \\
\text { two averages }\end{array}$} & \multirow[b]{2}{*}{ "t" value } \\
\hline & & & Standard & & Standard & & \\
\hline \multirow{4}{*}{$\begin{array}{c}\text { Technical } \\
\text { performance level }\end{array}$} & $\begin{array}{l}\text { From the beginning } \\
\text { to the first hurdle }\end{array}$ & 1.80 & 0.55 & 2.65 & 0.33 & 0.85 & $* 8.23$ \\
\hline & $\begin{array}{c}\text { Passing over the } \\
\text { hurdle }\end{array}$ & 1.15 & 0.33 & 2.03 & 0.26 & 0.88 & $* 14.23$ \\
\hline & $\begin{array}{c}\text { Running among } \\
\text { hurdles }\end{array}$ & 1.63 & 0.22 & 2.43 & 0.37 & 0.80 & $* 14.24$ \\
\hline & $\begin{array}{c}\text { From the last hurdle } \\
\text { to the end line }\end{array}$ & 1.70 & 0.35 & 2.53 & 0.38 & 0.83 & *7.91 \\
\hline \multicolumn{2}{|c|}{ Digital level } & 28.26 & 1.21 & 24.48 & 1.00 & 3.78 & $* 18.88$ \\
\hline
\end{tabular}

The value of " ${ }^{\prime \prime}$ indexed at the level $(0.05)=2.09$

It is clear from Table (4) that there are significant differences between the average of the pre and post measurements in the control group in the variables of performance level and in the digital level in favor of post measurement 
Table (5)

Significant differences between the average of the two post measurements in the two groups of research Experimental and control groups in tests of harmonic capacity $n=1 n 20=2$

\begin{tabular}{|c|c|c|c|c|c|c|c|c|}
\hline \multirow{2}{*}{\multicolumn{3}{|c|}{ Harmonic ability tests }} & \multicolumn{2}{|c|}{$\begin{array}{l}\text { The experimental } \\
\text { group }\end{array}$} & \multicolumn{2}{|c|}{ The control group } & \multirow{2}{*}{$\begin{array}{c}\text { The difference } \\
\text { between the two } \\
\text { averages }\end{array}$} & \multirow{2}{*}{$\begin{array}{c}\text { "t" } \\
\text { value }\end{array}$} \\
\hline & & & Mean & $\begin{array}{l}\text { Standard } \\
\text { deviation }\end{array}$ & Mean & $\begin{array}{l}\text { Standard } \\
\text { deviation }\end{array}$ & & \\
\hline \multicolumn{3}{|c|}{ Speed } & 4.49 & 0.49 & 4.98 & 0.46 & 0.49 & $* 3.25$ \\
\hline \multicolumn{3}{|c|}{ Rhythm } & 7.55 & 0.51 & 6.60 & 0.75 & 0.95 & $* 4.67$ \\
\hline \multicolumn{3}{|c|}{ Link } & 11.30 & 0.49 & 12.24 & 0.57 & 0.94 & $* 5.6$ \\
\hline \multicolumn{3}{|c|}{ Balance } & 70.85 & 5.45 & 68.25 & 5.34 & 2.60 & 1.52 \\
\hline \multicolumn{3}{|c|}{ Quick respond } & 7.57 & 0.34 & 7.99 & 0.33 & 0.42 & $* 3.94$ \\
\hline \multirow{6}{*}{$\begin{array}{l}\text { voltage } \\
\text { regulation }\end{array}$} & \multirow{2}{*}{$\begin{array}{l}\text { From the } \\
\text { beginning to the } \\
\text { first hurdle }\end{array}$} & time & 3.52 & 0.42 & 3.98 & 0.39 & 0.46 & $* 3.52$ \\
\hline & & form & 1.85 & 0.37 & 1.80 & 0.41 & 0.05 & 0.41 \\
\hline & \multirow{2}{*}{ Among hurdles } & time & 8.67 & 0.61 & 9.75 & 0.60 & 1.08 & $* 5.63$ \\
\hline & & form & 4.70 & 0.66 & 2.90 & 1.02 & 1.80 & $* 6.63$ \\
\hline & \multirow{2}{*}{$\begin{array}{l}\text { From the last } \\
\text { hurdle } \\
\text { to the end line }\end{array}$} & time & 2.81 & 0.42 & 3.08 & 0.34 & 0.27 & $* 2.26$ \\
\hline & & form & 1.9 & 0.31 & 1.75 & 0.44 & 0.15 & 1.24 \\
\hline
\end{tabular}

The value of " $v$ " indexed at the level $(0.05)=2.09$

It is clear from Table (5) that there are in experimental and control in tests of harmonic significant differences between the average of ability and in favor of the average in post post measurements of the two sets of research measurement of the experimental group.

Table (6)

Significant differences between the average of the two post measurements of the two experimental and control research groups. In Variables of performance level and of Digital level

$$
n=1 n 20=2
$$

\begin{tabular}{|c|c|c|c|c|c|c|c|}
\hline \multirow{2}{*}{\multicolumn{2}{|c|}{ Variables }} & \multicolumn{2}{|c|}{$\begin{array}{l}\text { The experimental } \\
\text { group }\end{array}$} & \multicolumn{2}{|c|}{ The control group } & \multirow{2}{*}{$\begin{array}{c}\text { The } \\
\text { difference } \\
\text { between the } \\
\text { two averages }\end{array}$} & \multirow{2}{*}{ "t" value } \\
\hline & & Mean & $\begin{array}{l}\text { Standard } \\
\text { deviation }\end{array}$ & Mean & $\begin{array}{l}\text { Standard } \\
\text { deviation }\end{array}$ & & \\
\hline \multirow{4}{*}{$\begin{array}{c}\text { Technical } \\
\text { performance level }\end{array}$} & $\begin{array}{l}\text { From the beginning } \\
\text { to the first hurdle }\end{array}$ & 3.68 & 0.37 & 2.65 & 0.33 & 1.03 & $* 9.23$ \\
\hline & $\begin{array}{l}\text { Passing over the } \\
\text { hurdle }\end{array}$ & 2.60 & 0.35 & 2.03 & 0.26 & 0.57 & $* 5.96$ \\
\hline & $\begin{array}{c}\text { Running among } \\
\text { hurdles }\end{array}$ & 3.35 & 0.33 & 2.43 & 0.37 & 0.92 & $* 8.33$ \\
\hline & $\begin{array}{l}\text { From the last hurdle } \\
\text { to the end line }\end{array}$ & 3.30 & 0.34 & 2.53 & 0.38 & 0.77 & $* 6.79$ \\
\hline \multicolumn{2}{|c|}{ Digital level } & 22.30 & 1.14 & 24.48 & 1.00 & 2.18 & $* 6.44$ \\
\hline
\end{tabular}

The value of " ${ }^{\prime \prime}$ indexed at the level $(0.05)=2.09$

It is clear from Table (6) that there are significant differences between the two averages of post measurements of the experimental and control search groups in the variables of the performance and the digital level in favor of the average of post measurement of the experimental group 


\section{Discussion:}

From the table (1), (2) it is clear that there are significant statistic differences between the average of the pre and post measurements for experimental group in tests of harmonic abilities and the level of technical and digital performance in favor of the post measurement average and this confirms that the harmonic abilities help to guide and set the performance in the first place and help to acquire and learn new skills speedily and use them appropriately and reach to a degree of skill performing proficiency and economizing the effort during the performance. As shown in Table (3), (4) , there are significant statistic differences between the two pre and post measurements averages of the control and experimental group in tests of harmonic abilities in the level of technical and digital performance ,in favor of the post measurement average and this confirms that the practice of sport regularly and the training to perform the skill lead to improve the level and access to a better performance. As shown in Table (5) that there are significant statistic differences between the two post measurements averages of the two research groups - experimental and control - in the harmonic abilities with the exception of the ability to balance - the technical form in the first and last stage of the ability to organize the effort) is not indicated statistically . The researcher attributes this to the use of the proposed program and This agrees with the study of both the B Hz B HIRTZ (7) and Nashwa Mahmoud (10) that putting the limited training programs have a positive impact on the improvement of harmonic abilities. As shown in Table (6) , there are a significant statistic differences between the two post measurements averages for the two research groups - experimental and control in the variables of the performance level and the digital and technical level for the experimental group and the researcher brings this back to limiting the harmonic training and the selection of appropriate exercises in the program which have the greatest effect in developing the performance level and this agrees with what Mohamed Lotfi Hassanein pointed at, (5) to that there is a close link between the harmonic ability ,technical skills and rising the performance level.

\section{Conclusions:}

1. The proposed program has led to improve the harmonic abilities of the 100-meter hurdles of the research sample.

2. The proposed program has led to improve the level of performance (technical and digital) of 100 meters hurdles of the research sample.

\section{References:}

1. Abdel-Fattah, Ahmed, Abu el -Ela: the biology of the sport, Knowledge House, i 8, Cairo, 1997.

2. Abdel-Khaliq, Essam: sports training theories and applications, Knowledge House, Cairo, 2003.

3. Allawi Hassan Mohamed: training and athletic competition Psychology, the Arab Thought House, Cairo, 2002.

4. Hamada Mohammed Jamal al-Din, Naga Salah survived : sport training (Duties Methods - Planning - calendar) 2003.

5. Hassanein ,Lotfi Mohamed: sports achievement and training business rules, applied vision, Center for the Book Publishing, Cairo, 2006.

6. Hassanein ,Sobhi, Mohamed: Evaluation and Measurement in Physical Education, Dar AlArab thought, i 4, Cairo, 1999.

7. Hirtz - B: schwerpunkte der doordindimative motorischen vervo lldomnungn sportunterrict $\mathrm{dr}$ klassem bis 10, nkorbererzienug, fachzaitschrift fur sport Lehrer trainer, and ubungsleiter 1987.

8. Jensen, c.R and fisher, A. C: scientific Basis of athletic conditioning 2 nd ed, Philadelphia lea and Fibiger, 1999.

9. Mathews, D, K: Measurement in physical education wanders company, Philadelphia 1981.

10. Nafi, Mahmoud Nashwa effectiveness of a program of exercises with the tools on some harmonic capacity and feeling of loneliness for the hearing impaired, Journal of Sport Science and the Arts, Volume 14, January, Faculty of 
Physical Education for Girls on the island, 11. walf Droge: freedicals in the physiological Helwan University, 2001. contol of fuction, American physiological society, January 2002. 
